\title{
Genetic variability of the Amazon River prawn Macrobrachium amazonicum (Decapoda, Caridea, Palaemonidae)
}

\author{
Fernanda G. Vergamini ${ }^{1}$, Leonardo G. Pileggi ${ }^{1}$, Fernando L. Mantelatto ${ }^{1,2}$ \\ ${ }^{1}$ Laboratory of Bioecology and Crustacean Systematics, Postgraduate Program in Comparative Biology, Depart- \\ ment of Biology, Faculty of Philosophy, Science and Letters of Ribeirão Preto (FFCLRP), University of São Paulo \\ (USP), Bandeirantes Av., 3900, 14040-901, Ribeirão Preto, SP, Brazil \\ ${ }^{2}$ E-mail:flmantel@usp.br
}

Key words: Brazil, genetic distance, inland versus coastal populations, phylogeny, mitochondrial DNA, population structure

\begin{abstract}
The freshwater prawn Macrobrachium amazonicum is widely distributed in South America, and occupies habitats with a wide range of salinities. Several investigations have revealed the existence of wide intraspecific variability among different populations, although the understanding of this variability is still fragmentary and incomplete. We compared and characterized inland and coastal populations of M. amazonicum from Brazil, using molecular data (16S and COI mtDNA) to describe the degree of variability, structure, and relationships among them. Genetic divergence rates among populations showed variability at the intraspecific level. All the analyses evidenced significant genetic divergence among populations, structuring them in three groups: I- inland waters of the Amazonian Hydrographic Region (HR); II- Paraná/Paraguay HR; and III- coastal systems of northern and northeastern Brazil. Phylogenetic reconstructions revealed that the populations form a single monophyletic clade, which supports their characterization as a single species. Clade I was a sister clade of that formed by clades II and III, which were themselves sister clades. Populations from Sertãozinho/Miguelópolis and Avaré, introduced into the state of São Paulo, may have originated from natural populations in the states of Mato Grosso do Sul and Pará, respectively. Geographical isolation probably contributed to the observed variation, and if this isolation continues, M. amazonicum may undergo speciation within its broad geographical distribution. The sequences obtained here can be used as name-tags for population identification, and the DNA barcodes are useful to identify the origin of specimens used in different freshwater-prawn cultures or introduced populations of unknown origin.
\end{abstract}

\section{Contents}

Introduction 67

Material and methods

Sample collection

DNA extraction, amplification, and sequencing ............. 70

Phylogenetic analyses ................................................... 71

Distance analyses ………............................................ 71

Population analyses

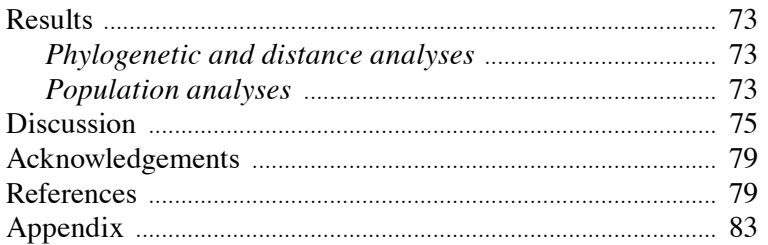

\section{Introduction}

Many species of the 'freshwater' prawn genus Macrobrachium Bate, 1868 require access to the sea during their larval development (Short, 2004). The members of this genus have three types of reproductive strategies: the first type has extended larval development that depends on marine access; the second includes species with distributions including inland and coastal waters, and their larval development is more or less extended; and the third type includes species with abbreviated larval development that are independent of marine influence and are restricted to inland waters (Williamson, 1973; Magalhães and Walker, 1988; Bueno and Rodrigues, 1995; Alekhnovich and Kulesh, 2001). The Amazon River prawn Macrobrachium amazonicum (Heller, 1862) is of the second type (Magalhães and Walker, 1988; Alekhnovich and Kulesh, 2001), and occupies a wide range of salinities, from fresh water (Gamba, 1984; Magalhães, 1985; Bialetzki et al., 1997; Gamba, 1997; Porto, 1998; Magalhães, 2000; Hayd and Nakagaki, 2002; Magalhães et al., 2005) to estuaries (Barreto and Soares, 1982; Vega-Pérez, 1984; Lobão et al., 1986; Odinetz-Collart and Rabelo, 1996; Peixoto, 2002; Silva et al., 2007).

Macrobrachium amazonicum is endemic to South America, with a wide geographical distribution including the Amazon and Orinoco river basins and rivers 
between these basins (Holthuis, 1952; Odinetz-Collart and Rabelo, 1996), as well as rivers and estuaries in the Guyanas, Venezuela, Colombia, and the northern and northeastern coasts of Brazil (Holthuis, 1952; Melo, 2003; Valencia and Campos, 2007). Inland populations have been recently reported from the Upper Paraná and Paraguay basin in Brazil (Bialetzki et al., 1997; Magalhães, 2000; Hayd and Nakagaki, 2002; Melo, 2003; Magalhães et al., 2005; Anger et al., 2009), Panama and Peru (FLM and LGP, pers. obs.), Bolivia, Paraguay (Melo, 2003), and Argentina (Pettovello, 1996). The presence of this species in Central America (Nicaragua and Costa Rica) has been conjectured by local people and researchers during a field trip by one of us (FLM), but no material is presently available for analysis.

The presumptive natural distribution of M. amazonicum includes the Orinoco, Amazon, and Paraguay/ Lower Paraná river basins (Magalhães et al., 2005). The species probably evolved in one of these regions and then dispersed across these paleobasins after subsequent geological events shifted their boundaries
(Magalhães et al., 2005 for review). Accordingly, the presence of M. amazonicum in northeastern and eastern Brazil and in the Upper Paraná River basin is considered to be unnatural and probably a result of humanmediated dispersal, either accidentally or for aquaculture (Coelho, 1963; Pinto, 1977; Magalhães et al., 2005). Macrobrachium amazonicum may have been introduced into the state of São Paulo between 1966 and 1973 together with M. jelskii (Miers, 1877) in the CESP (Companhia Energética de São Paulo) fish-farming stations, as part of the process of transplanting the fish Plagioscion squamosissimus (Heckel, 1840) from reservoirs in northeastern Brazil (Torloni et al., 1993). Some small fish were reported to have escaped to natural environments, and the prawns could have followed the same dispersal route (Magalhães et al., 2005).

Macrobrachium amazonicum could also have been transplanted to some localities in São Paulo from natural populations occurring in the Pantanal, in the state of Mato Grosso do Sul. The prawns may have been accidentally transported together with some fish species caught in natural environments, to stock ponds

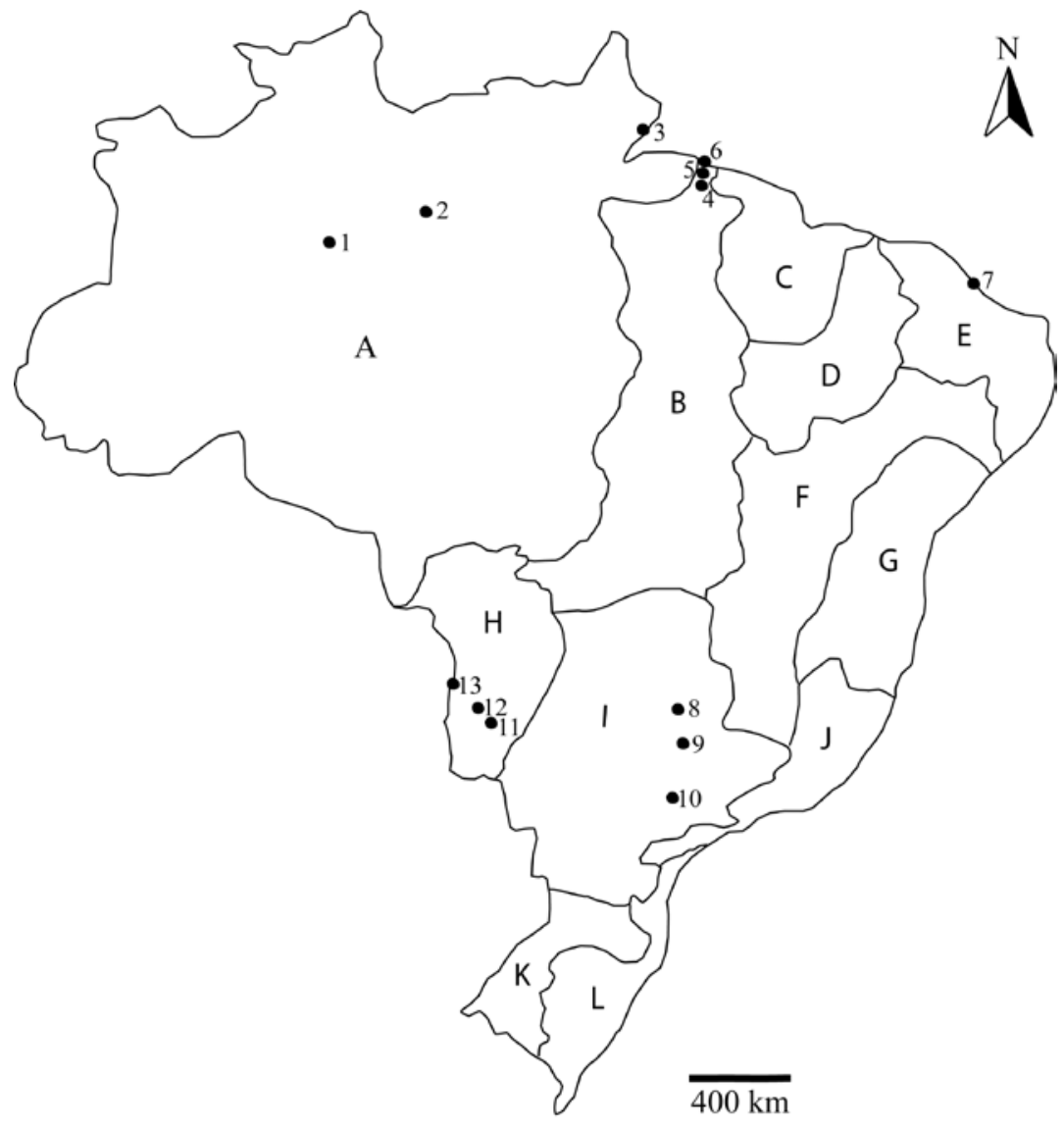

Fig. 1. Collection localities in Brazil for Macrobrachium amazonicum samples used in this study. Locations of sampling sites (city and state, respectively): 1: Tapauá, Amazonas; 2: Itacoatiara, Amazonas; 3: Santana, Amapá; 4: Abaetetuba, Pará; 5: Belém, Pará; 6: Santa Bárbara, Pará; 7: Aquiraz, Ceará; 8: Miguelópolis, São Paulo; 9: Sertãozinho, São Paulo; 10: Avaré, São Paulo; 11: Aquidauana, Mato Grosso do Sul; 12: Miranda, Mato Grosso do Sul; 13: Corumbá, Mato Grosso do Sul. Hydrographic Regions in the Brazilian territory: A: Amazonian; B: Tocantins/Araguaia; C: Western North-east Atlantic; D: Parnaíba; E: Eastern Northeast Atlantic; F: São Francisco; G: Eastern Atlantic; H: Paraguay; I: Paraná: J: South-eastern Atlantic; K: Uruguay, and L: South Atlantic. 
and reservoirs used in sport fishing, where people pay per weight of fish caught. This sport is widespread in the state of São Paulo (Magalhães et al., 2005). Another likely reason for the establishment of $M$. amazonicum in the Upper Paraná River basin is the inundation of the Guaíra Falls after the formation of the Itaipu Reservoir in 1982. The removal of this barrier made it possible for several aquatic species to travel upstream into the upper basin (Magalhães et al., 2005).

Knowledge of variability among populations of $M$. amazonicum inhabiting different environments has accumulated in recent years. Inland populations show different reproductive strategies from estuarine populations (A.L. Meireles, W.C. Valenti, and FLM, unpublished data); the egg size seems to increase as distance from the ocean increases (Odinetz-Collart and Rabelo, 1996); independent populations show considerable variation in the osmoregulatory and survival capability of larval and adult stages (Augusto et al., 2007); the maximum size attained by adults differs between populations from rivers and lakes (Odinetz-Collart, 1987; Odinetz-Collart and Moreira, 1993; Odinetz-Collart and Magalhães, 1994); there is variability among some inland and coastal populations from northern Brazil (Peixoto, 2002); a morphometric analysis suggested the partition of populations from Brazil into two different species (Porto, 2004); and larval morphology differs among some populations (Anger et al., 2009). However, the entire life cycle of this species is still under investigation.

This extensive intraspecific variability may be due to genetic isolation of populations, and possibly an incipient speciation process (Anger et al., 2009). This condition makes $M$. amazonicum an ideal candidate for comparative studies on population features and evolution throughout its geographical distribution.

In heterogeneous or geographically isolated environments, a single species may have genetically diversified and structured populations. Molecular markers can be useful in delimiting boundaries between lineages and/or species, as well as in studies of intra- and interspecific relationships (Liu et al., 2007; Baker et al., 2008). As far as we are aware, knowledge of the genetic variability of $M$. amazonicum is restricted to the unpublished thesis by Peixoto (2002), which examined the cytochrome c oxidase subunit I gene - COI) for a small number of populations from northern Brazil.

Considering that M. amazonicum has a good potential in Brazilian freshwater prawn aquaculture (Moraes-Riodades and Valenti, 2001, 2004; Maciel and Valenti, 2009 for review) and that knowledge of its life history remains fragmentary (Anger et al., 2009; Maciel and Valenti, 2009), the need is evident for complementary studies evaluating the degree of variability among the diversified populations of this species. This led us to evaluate the level of genetic variability and structure among several inland and coastal populations of M. amazonicum, covering a wide geographical range in Brazil, using mtDNA data (16S and COI). We also investigated the phylogenetic relationships among these populations and whether they constitute a monophyletic clade.

\section{Material and methods}

\section{Sample collection}

We used specimens from most of the coastal and inland regions of Brazil where this species has been reported to date. Thirteen populations of M. amazonicum were analyzed, from throughout the country (Fig. 1). The populations were classified according to the Brazilian National Hydrographic Division (Brasil, 2003) and the influence of brackish water (coastal: those restricted to river systems close to the seacoast, with brackish water influence; and inland: those found in inland river systems with no connection to the coast).

Coastal populations covered the following Hydrographic Regions (HR): Amazonian, Tocantins-Araguaia, and Eastern/Northeast Atlantic (Fig. 1). The inland populations were divided in two groups: Amazonian HR, and Paraguay and Paraná HR (Fig. 1). Inland populations sampled in the state of São Paulo and along the northeastern Brazilian coast were classified as introduced, because of their unnatural distributions (Magalhães et al., 2005).

Some specimens were obtained from field collections, carried out in compliance with current applicable state and federal laws of Brazil (DIFAP/IBAMA, 126/2005; permanent license for collection of Zoological Material No. 11777-1 MMA/IBAMA/SISBIO). These specimens were incorporated into the Crustacean Collection of the Biology Department (CCDB) of the Faculty of Philosophy, Sciences and Letters of Ribeirão Preto (FFCLRP) and the University of São Paulo (USP) (Appendix). Complementary specimens were acquired by donation or loan from crustacean collections, or were collected and sent to us by collaborating researchers from several institutions in Brazil (Appendix). Donated material was preserved directly in $80 \%$ ethanol and deposited in the CCDB. 
The identifications were based on the diagnostic morphological traits of M. amazonicum (Heller, 1862; Holthuis, 1952; Gomes-Corrêa, 1977; Melo, 2003).

Based on the proposed phylogeny for Macrobrachium by Pileggi and Mantelatto (2010), we identified the species that are more closely related and reliably distant from M. amazonicum, to compose the outgroup in our analyses (Appendix).

\section{DNA extraction, amplification, and sequencing}

All sequences used in this study were generated from our own extractions for this project. When possible, the analyses used three to ten specimens from each collection site, in order to limit the chance of misidentifications and variability. Genetic vouchers, from which tissue samples were obtained, were deposited in appropriate collections (Appendix). All procedures followed Mantelatto et al. (2007, 2009a) and Pileggi and Mantelatto (2010), with appropriate modifications. Total genomic DNA was extracted from the abdomen or from the pereiopod muscle tissue.

A polymerase chain reaction (PCR) was conducted in a Thermo ${ }^{\circledR}$ PxE 0.2 Thermal Cycler, using the universal primers for invertebrates: 16Sar (5'-CGCCTGTTTATCAAAAACAT-3') and 16Sbr (5'-CCGGTCTGAACTCAGATCACGT-3') (Palumbi et al., 1991) for the 16S rRNA (the large subunit of the ribosomal

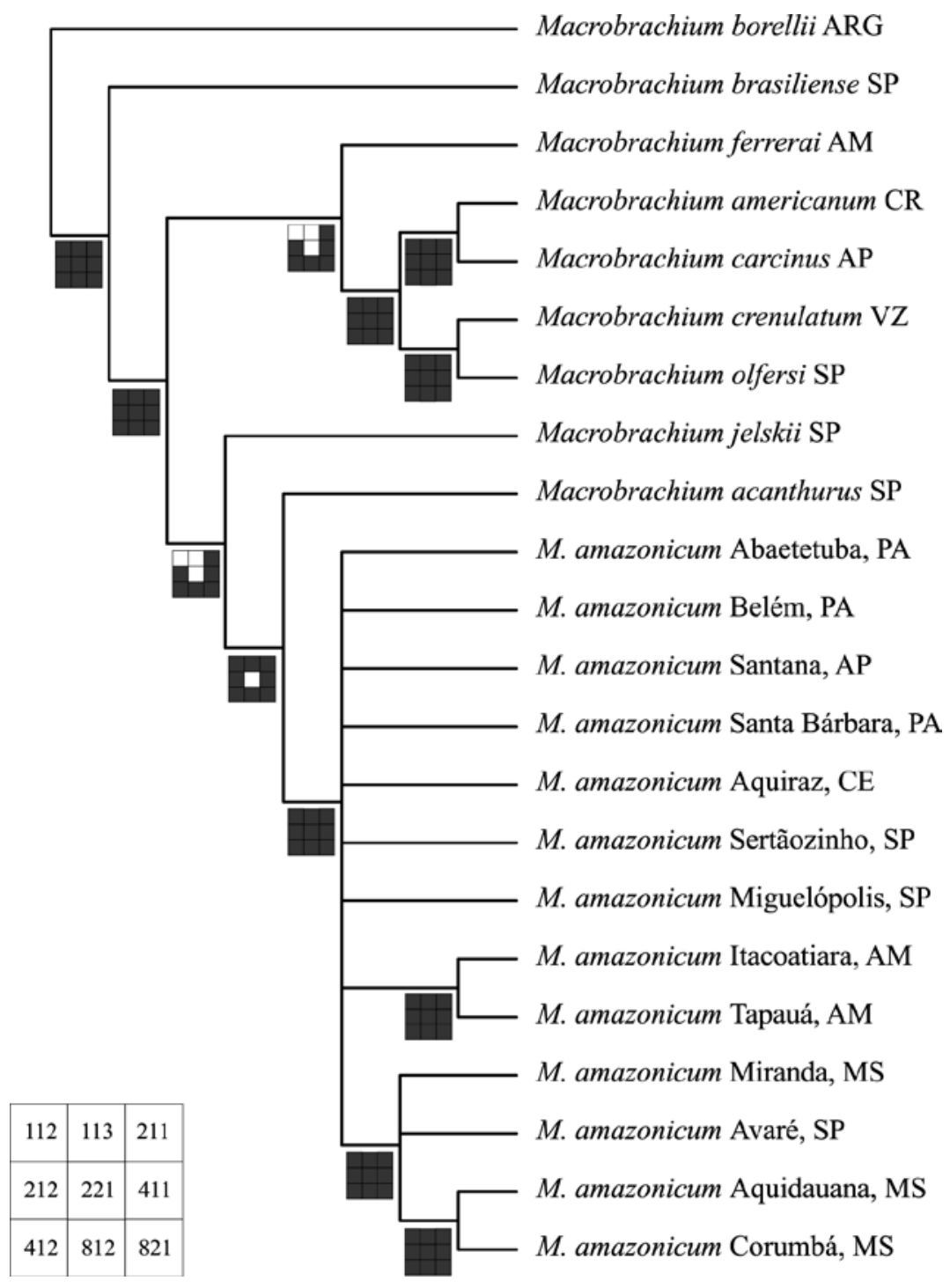

Fig. 2. Phylogenetic tree for populations of Macrobrachium amazonicum from Brazil based on direct optimization analysis of 16S rRNA data sets. The box on the left/down side indicates the parameter sets used in the sensitivity analysis. Filled boxes correspond to the parameters under which the clade was stable. ARG: Argentina. CR: Costa Rica. VZ: Venezuela. Brazilian states: AM: Amazonas; AP: Amapá; CE: Ceará; MS: Mato Grosso do Sul; PA: Pará; SP: São Paulo. 
rRNA), and COI-a (5'-AGTATAAGCGTCTGGGTAG TC-3') and COI-f (5'-CCTGCAGGAGGA GGAGACCC-3') (Palumbi and Benzie, 1991) for the COI gene. PCR products were purified using Microcon $100^{\circledR}$ filters and a SureClean Plus kit, and were sequenced with the ABI Big Dye ${ }^{\circledR}$ Terminator Mix in an ABI Prism 3100 Genetic Analyzer ${ }^{\circledR}$ following Applied Biosystems protocols. All sequences were confirmed by sequencing both strands. The consensus sequence for the two strands was obtained using BioEdit Version 7.0.7.1 (Hall, 1999). Sequences were edited using BioEdit and aligned in Clustal W (Thompson et al., 1994) with interface in BioEdit, with default parameters. All sequences were submitted to GenBank (Appendix).

\section{Phylogenetic analyses}

It is recommended that, at least preliminarily, the phylogenetic relationships that delimit a monophyletic group be resolved, so that an analysis can be undertaken with only one segment of this group (Amorim, 2002). Considering Macrobrachium as a natural group (Murphy and Austin, 2005; Lui et al., 2007; Pileggi and Mantelatto, 2010), our phylogenetic analysis focusing on M. amazonicum populations can be considered relevant and justified.

The gaps from the 16S mtDNA sequences, which are due to real gaps in the alignment, were removed in order to obtain non-aligned sequences. No gaps were found in the alignment of COI sequences. These sequences were analyzed in POY Version 4.0 (Varón et al., 2007) using the direct optimization method, with parsimony as the optimality criterion (Wheeler, 1996). This methodology has given consistent results in recent molecular phylogenies of crustaceans (Mantelatto et al., 2009b; Pileggi and Mantelatto, 2010). Topologies were constructed through random addition sequence, followed by a combination of refinement parameters. Sensitivity analysis was carried out using different cost matrices, as suggested by Wheeler (1995). All data sets for the parsimony analysis were analyzed under 10 parameter sets for a range of indels, transition, and transversion ratios. The matrix digits $(111,112,113,211,212,221,411,412,812$, and 821) correspond to the ratio of indel/transversion/transition values, respectively.

\section{Distance analyses}

Distance analyses were carried out by the static alignment procedure for both gene sequences. Am- biguous regions of the sequences were removed. Substitution models used in distance matrix calculations were previously selected under the Akaike Information Criterion (AIC) (Posada and Buckley, 2004) among 56 available alternatives of the program ModelTest Version 3.7 (Posada and Crandall, 1998). Matrix data were grouped by Neighbor Joining (NJ) (Saitou and Nei, 1987) in PAUP Version 4.0 beta10 (Swofford, 2003) using the maximum-likelihood distance correction set. The consistency of topologies was measured by the bootstrap method (Felsenstein, $1985)$ with 1000 replicates; only confidence values $>$ $50 \%$ were reported. In order to estimate intra- and interspecific divergence rates, genetic distances were also calculated in PAUP using the $\mathrm{p}$ distance. All positions were compared directly for each pair of sequences, one at a time.

\section{Population analyses}

In this analysis, we considered COI sequences from coastal and inland populations of M. amazonicum. The haplotype number was calculated in DnaSP Version 4.10.9 (Rozas and Rozas, 1999). The haplotype and nucleotide diversities were calculated for each population using Arlequin Version 3.1 (Excoffier et al., 2005).

Haplotype networks were constructed by the statistical parsimony method in TCS (Version 1.21) (Clement et al., 2000) and by the Median-Joining method in Network (Bandelt et al., 1999), with data preparation in DnaSP. Networks were constructed in two phases. First, introduced populations with an unnatural distribution (Appendix, Fig. 1) were not included because their origins are unknown, and the results could be skewed or masked by their presence in the analysis. In a second phase, when the genetic variability among natural populations had been estimated, an analysis with all populations was carried out so that the probable origin of the introduced populations could be inferred.

Series of analyses of molecular variance (AMOVA) (Excoffier et al., 1992) were computed in Arlequin to examine the distribution of genetic variation. Analyses were run based on haplotype frequencies with no hierarchical structure (all populations in a single group) and with regional subdivisions defined according to the results of the haplotype networks. The significance was tested using a nonparametric permutation procedure (Excoffier et al., 1992), incorporating 10,000 permutations. 


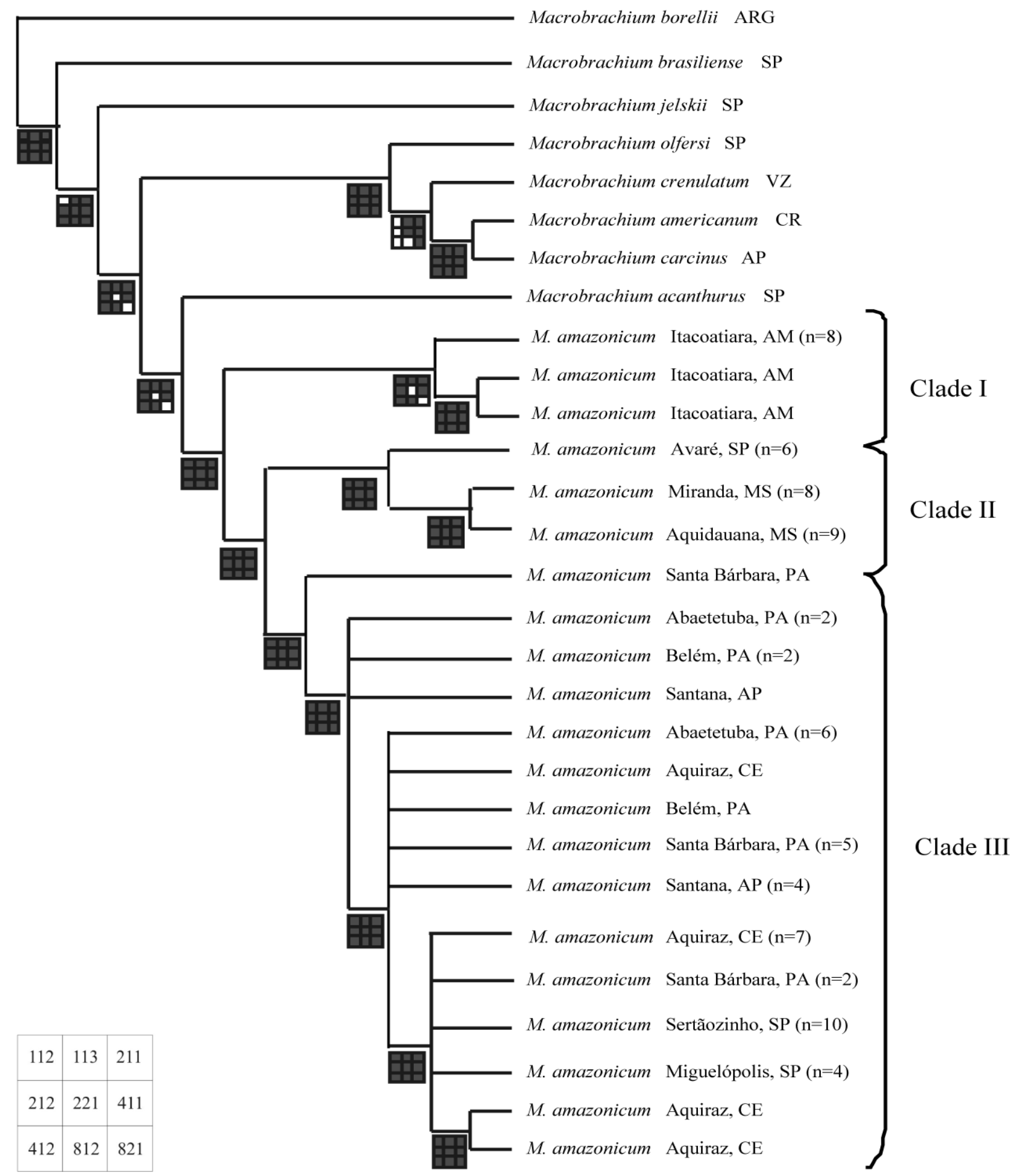

Fig. 3. Phylogenetic tree for populations of Macrobrachium amazonicum from Brazil based on direct optimization analysis of COI data sets. The box on the left/down side indicates the parameter sets used in the sensitivity analysis. Filled boxes correspond to the parameters under which the clade was stable. ARG: Argentina. CR: Costa Rica. VZ: Venezuela. Brazilian states: AM: Amazonas; AP: Amapá; CE: Ceará; MS: Mato Grosso do Sul; PA: Pará; SP: São Paulo. Clades: I - inland population from Amazonian Hydrographic Region (HR); II - inland populations from Paraná/Paraguay HR; III - coastal populations from northern and north-eastern Brazil. 


\section{Results}

\section{Phylogenetic and distance analyses}

We acquired 16S rRNA gene partial sequences with 540 aligned base pairs (bp) from 22 specimens, of which 13 were M. amazonicum (each representing a different population) and 9 were other Macrobrachium species (outgroup) (Appendix). The COI sequences were 569 bp in length, obtained from 89 specimens, 81 of which were M. amazonicum from 11 sites in different regions of Brazil, and 8 from the outgroup (Appendix).

The analyses of different methodologies (distance and parsimony methods) and different mitochondrial genes (16S and COI) resulted in similar tree topologies with several clades, which were found in all cases (Figs 2-5). Macrobrachium amazonicum formed a distinct group, with M. acanthurus (Wiegmann, 1836) and $M$. jelskii as the closest clades, respectively.

In the phylogenetic analyses, of the 10 parameter sets used in the direct optimization analysis, the set that produced the shortest trees had 1:1:1 indels/transition/transversion ratio (Matrix 111), for both $16 \mathrm{~S}$ and COI sequences. The $16 \mathrm{~S}$ sequences yielded two parsimonious trees of length 270 , while for the COI sequences, four trees of length 485 were found. In our parsimony analyses, M. amazonicum was consistently found to be monophyletic in all trees during the sensitivity analysis (Figs 2-3).

In distance analyses, the optimal model for the $16 \mathrm{~S}$ data set, selected under AIC, was the transversional model of sequence evolution (Posada and Crandall, 1998) plus gamma distributed rate heterogeneity $(\mathrm{TVM}+\mathrm{G})$ with the following parameters: assumed nucleotide frequencies $\mathrm{A}=0.3038, \mathrm{C}=0.1142, \mathrm{G}=$ $0.2205, \mathrm{~T}=0.3616$; proportion of invariable sites $\mathrm{I}=0$; the variable sites followed a gamma distribution, with shape parameter $=0.1593$. For the COI data set, the chosen model was the Hasegawa, Kishino, Yano 85 model of sequence evolution (Hasegawa et al., 1985) plus gamma distributed rate heterogeneity with a significant proportion of invariable sites $(\mathrm{HKY}+\mathrm{I}+\mathrm{G})$, with the following parameters: assumed nucleotide frequencies $\mathrm{A}=0.2463, \mathrm{C}=0.1256, \mathrm{G}=0.3036, \mathrm{~T}=$ 0.3245 ; proportion of invariable sites $\mathrm{I}=0.5410$; the variable sites followed a gamma distribution, with shape parameter $=0.4135$.

The 16S phylogeny showed that specimens of $M$. amazonicum from Itacoatiara and Tapauá, located in the state of Amazonas in the Amazonian HR, were closely related. Similarly, specimens from Aquidauana and Corumbá in Mato Grosso do Sul (Paraguay HR) constituted a distinct group (Fig. 2). In general it was not possible to identify the relationships among the populations because of the large number of unsolved steps within the M. amazonicum clade (Fig. 2).

Considering the NJ dendrogram based on $16 \mathrm{~S}$ sequences, we identified three small subgroups, which are closely related to each other (Fig. 4): specimens from the Paraná/Paraguay HR (sample sites 10-13, Fig. 1); specimens from the Amazonian HR (sites 1-2, Fig. 1); and from coastal and São Paulo populations (sites 6-7 and 8-9, respectively, Fig. 1). It was not possible to assess the genetic distance between these subgroups and the other analyzed specimens. The close similarity between sequences reflected the unsolved steps in the dendrogram (Fig. 4).

On the other hand, both the COI phylogeny and the $\mathrm{NJ}$ dendrogram clearly evidenced three distinct clades (Figs 3, 5): I- inland population from the Amazonian HR (sample site 2, Fig. 1); II- inland populations from the Paraná/Paraguay HR (sites 10-12, Fig. 1), and IIIcoastal populations from northern and northeastern Brazil (sites 3-7, Fig. 1) and two populations from the state of São Paulo (sites 8- 9, Fig. 1). Clade I was a sister group of that formed by clades II and III, which themselves formed sister groups. The relationships within each group were not well resolved in the phylogeny (Fig. 3).

We observed that, for $16 \mathrm{~S}$, interspecific distance among Macrobrachium ranged from 4.8-14.7\%, whereas the intraspecific (among M. amazonicum populations) ranged from $0-1.1 \%$. For COI sequences, the interspecific distance varied from 13.2-19.9\%, whereas the intraspecific distance ranged from $0-3.3 \%$.

\section{Population analyses}

We acquired sequence data for 81 specimens of $M$. amazonicum collected from 11 different sites. Based on a $569 \mathrm{bp}$ COI fragment of unambiguous sequence, we identified 13 haplotypes (H), of which 4 (30.4\%) represented single individuals. Of the 569 bp sequenced, $29(5.1 \%)$ were polymorphic. Substitution patterns favoured transitions (Ts) over transversions (Tv), and the Ts:Tv ratio was high (28:1). Only specimens from coastal populations and two populations from the state of São Paulo shared haplotypes. Although total haplotype diversity $(0.8488)$ was relatively high, four populations showed null nucleotide and haplotype diversities, with all individuals sharing the same haplotype (see Table 1). 


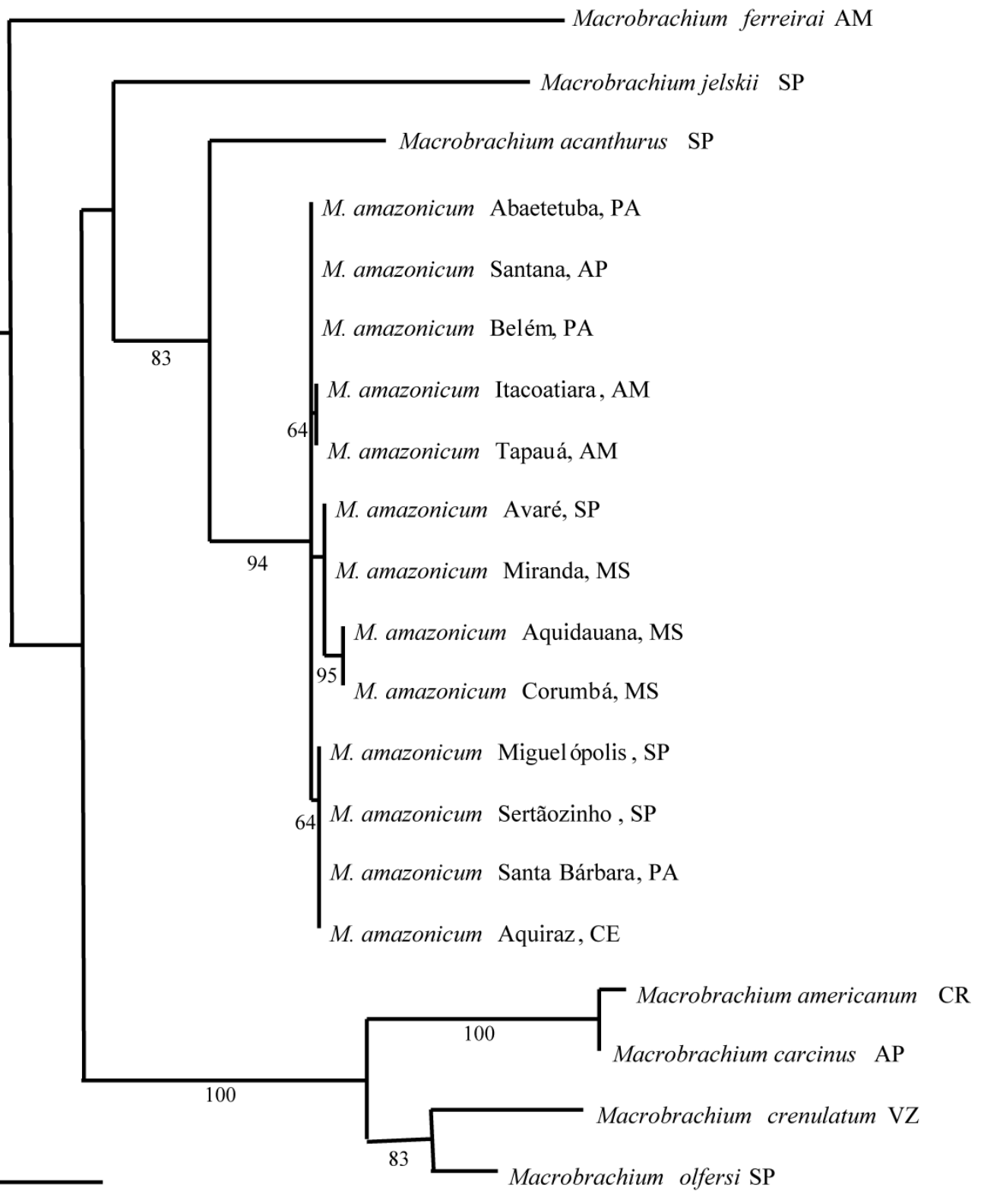

Fig. 4. Dendrogram for Macrobrachium amazonicum populations from Brazil based on Neighbor-Joining analysis of 16S rRNA gene sequences. Numbers above are significance values for 1000 bootstraps; values $\leq 50 \%$ are not shown. ARG: Argentina. CR: Costa Rica. VZ: Venezuela. Brazilian states: AM: Amazonas; AP: Amapá; CE: Ceará; MS: Mato Grosso do Sul; PA: Pará; SP: São Paulo.

Whether or not the introduced populations were included, it was evident, by both methods of network construction, that the haplotype network was divided into three groups (Fig. 6), exactly the same ones revealed by parsimony analysis with COI (Fig. 3). No haplotype was shared between the groups. 
Table 1. Distribution of haplotypes detected in Macrobrachium amazonicum from Brazil.

\begin{tabular}{|c|c|c|c|c|c|c|c|c|c|c|c|c|c|c|c|c|}
\hline \multirow[t]{2}{*}{ Populations } & \multicolumn{13}{|c|}{ Haplotype } & \multirow[t]{2}{*}{$\mathrm{N}$} & \multirow[t]{2}{*}{ Hd } & \multirow[t]{2}{*}{$\mathrm{Nd}+\mathrm{Sd}$} \\
\hline & 1 & 2 & 3 & 4 & 5 & 6 & 7 & 8 & 9 & 10 & 11 & 12 & 13 & & & \\
\hline 2 / Itacoatiara, AM & & & & & & & & & & 2 & 1 & 1 & 6 & 10 & 0.64 & $2.42 \times 10^{-3} \pm 1.84 \times 10^{-3}$ \\
\hline 3 / Santana, AP & 4 & 1 & & & & & & & & & & & & 5 & 0.40 & $0.70 \times 10^{-3} \pm 0.89 \times 10^{-3}$ \\
\hline 4 / Abaetetuba, PA & 6 & 2 & & & & & & & & & & & & 8 & 0.43 & $0.75 \times 10^{-3} \pm 0.86 \times 10^{-3}$ \\
\hline 5 / Belém, PA & 1 & 2 & & & & & & & & & & & & 3 & 0.67 & $1.17 \times 10^{-3} \pm 1.46 \times 10^{-3}$ \\
\hline 6 / Santa Bárbara, PA & 5 & & 2 & & 1 & & & & & & & & & 8 & 0.61 & $1.63 \times 10^{-3} \pm 1.42 \times 10^{-3}$ \\
\hline $7 /$ Aquiraz, $\mathrm{CE}^{\bullet}$ & 1 & & 7 & 2 & & & & & & & & & & 10 & 0.51 & $0.98 \times 10^{-3} \pm 0.98 \times 10^{-3}$ \\
\hline 8 / Miguelópolis, SP• & & & 4 & & & & & & & & & & & 4 & 0.00 & $0.00 \pm 0.00$ \\
\hline 9 / Sertãozinho, SP• & & & 10 & & & & & & & & & & & 10 & 0.00 & $0.00 \pm 0.00$ \\
\hline 10 / Avaré, SP• & & & & & & & 1 & & 5 & & & & & 6 & 0.33 & $0.59 \times 10^{-3} \pm 0.77 \times 10^{-3}$ \\
\hline 11 / Aquidauana, MS & & & & & & 9 & & & & & & & & 9 & 0.00 & $0.00 \pm 0.00$ \\
\hline 12 / Miranda, MS & & & & & & & 8 & & & & & & & 8 & 0.00 & $0.00 \pm 0.00$ \\
\hline Total & 17 & 5 & 23 & 2 & 1 & 9 & 8 & 1 & 5 & 2 & 1 & 1 & 6 & 81 & 0.85 & $16.97 \times 10^{-3} \pm 8.71 \times 10^{-3}$ \\
\hline
\end{tabular}

Populations: the numbers before the sample site name correspond to the ones used in Fig. 1. N: number of analyzed individuals in each population. Hd: haplotype diversity. Nd: nucleotide diversity. Sd: standard deviation. • Introduced populations. Brazilian states: AM: Amazonas; AP: Amapá; CE: Ceará; MS: Mato Grosso do Sul; PA: Pará; SP: São Paulo.

Regarding populations introduced in the state of São Paulo, specimens from Sertãozinho and Miguelópolis shared haplotypes with specimens from group III, specifically with individuals from Aquiraz and from the state of Pará; whereas specimens from Avaré showed haplotypes closely related to those found in group II. Specimens from Aquiraz, probably also an introduced population, shared haplotypes with individuals from coastal populations in the state of Pará (Fig. 6).

Analysis of molecular variance without hierarchical structure indicated that the highest percentage of variation (95.74\%) was among M. amazonicum populations, whereas the variation within each population was extremely low (4.26\%). When populations were structured according to the groups indicated by all the analyses (phylogenetic, distance, and haplotype network), significant levels of genetic variation were detected. Variations among populations within groups and within populations were very low (see Table 2).

\section{Discussion}

The present investigation, based upon analysis of a partial fragment of mtDNA genes, is the first to describe the phylogenetic position and genetic variability of Macrobrachium amazonicum from a wide geo-

Table 2. Analysis of molecular variance in Brazilian Macrobrachium amazonicum.

\begin{tabular}{|c|c|c|c|c|}
\hline AMOVA structure & Source of variation & Percentage & $\mathrm{F}_{\mathrm{st}} / \mathrm{F}_{\mathrm{ct}}$ & $\mathrm{P}$ \\
\hline Without & $\begin{array}{l}\text { among populations } \\
\text { within populations }\end{array}$ & $\begin{array}{r}95.74 \\
4.26\end{array}$ & 0.957 & $<0.001$ \\
\hline Coastal, Amazonian Hydrographic Region (HR) and Paraná/ & among groups & 93.27 & 0.933 & $<0.001$ \\
\hline Paraguay HR (introduced populations excluded) & $\begin{array}{l}\text { among populations } \\
\text { within groups }\end{array}$ & 3.29 & 0.488 & $<0.001$ \\
\hline \multirow{4}{*}{$\begin{array}{l}\text { Coastal, Amazonian HR and Paraná/ Paraguay HR (introduced } \\
\text { populations grouped following the haplotype networks results) }\end{array}$} & within populations & 3.44 & 0.965 & $<0.001$ \\
\hline & among groups & 92.26 & 0.922 & $<0.001$ \\
\hline & $\begin{array}{l}\text { among populations } \\
\text { within groups }\end{array}$ & 4.99 & 0.645 & $<0.001$ \\
\hline & within populations & 2.75 & 0.972 & $<0.001$ \\
\hline
\end{tabular}




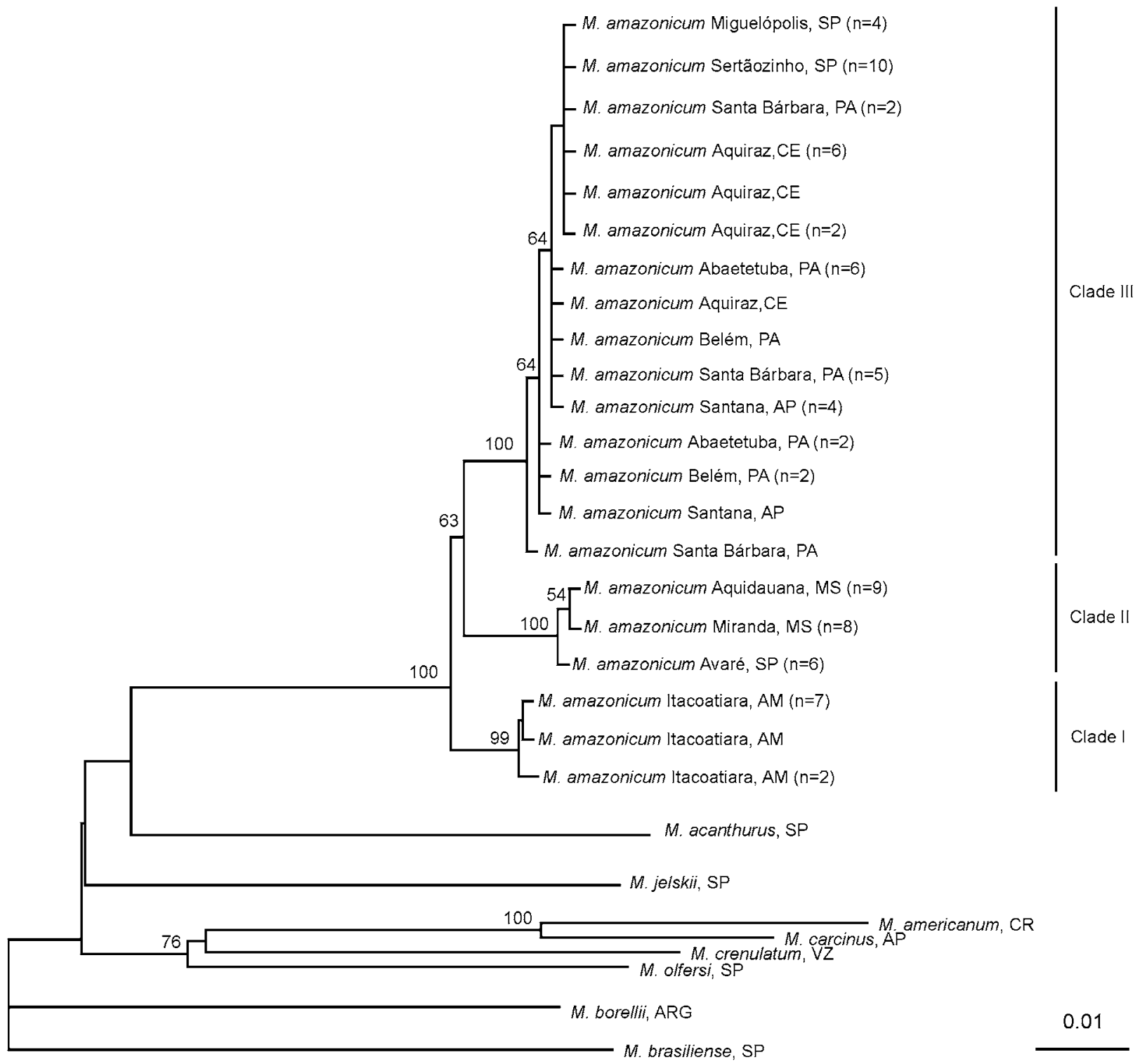

Fig. 5. Dendrogram for Macrobrachium amazonicum populations from Brazil based on Neighbor-Joining analysis of COI gene sequences. Numbers above are significance values for 1000 bootstraps; values $\leq 50 \%$ are not shown. ARG: Argentina. CR: Costa Rica. VZ: Venezuela. Brazilian states: AM: Amazonas; AP: Amapá; CE: Ceará; MS: Mato Grosso do Sul; PA: Pará; SP: São Paulo. Clades: I - inland population from Amazonian Hydrographic Region (HR); II - inland populations from Paraná/Paraguay HR; III - coastal populations from northern and north-eastern Brazil.

graphical range of inland and coastal sites. Our findings revealed important aspects of the evolutionary history of the species, especially regarding natural versus unnatural and inland versus coastal populations.

The first important information was that these populations of $M$. amazonicum composed one monophyletic clade, which ranks them as a single species according to the Phylogenetic Species Concepts sensu Mishler and Theriot (2000). Organisms are grouped into species rather than at some higher level because they are the least inclusive taxon recognized in a formal phylogenetic classification, and because they are the smallest monophyletic group deemed worthy of formal recognition (Mishler and Theriot, 2000). The positioning of M. amazonicum in the genus concords 
with a previous phylogenetic analysis of Macrobrachium (Pileggi and Mantelatto, 2010), in which $M$. acanthurus and M. jelskii appear as related taxa. A morphologically based analysis by Pileggi (2009) indicated that $M$. jelskii shares significant similarities with inland populations of M. amazonicum from the Upper Paraná and Paraguay basin in Brazil, and that $M$. acanthurus shares significant similarities with coastal populations of M. amazonicum.

Phylogenetic analyses with COI sequences revealed that an ancestral population originated the inland population of M. amazonicum from the Amazonian HR (clade I), and another ancestral population gave rise to the inland populations of the Paraná/Paraguay HR (clade II) and the coastal populations from northern and northeastern Brazil (clade III). Populations from clades II and III shared common ancestry, and were more closely related to each other than to individuals from clade I. Distance analyses showed the same structure described above. More detailed information about the relationships among the populations could not be obtained because the COI gene was not variable enough to provide sufficient resolution.

The inclusion of specimens from other localities than those used here, especially from the Amazonian HR owing to its immense geographical extent, would make possible a more profound reconstruction of the origin, life history, and phylogenetic relationships of M. amazonicum populations. It is also essential to add specimens from other countries in South and Central Americas.

Analyses with 16S rRNA gene sequences were not informative concerning phylogenetic and distance relationships among the populations, because of the small variation among the specimens (genetic divergence from 0 to $1.1 \%$ ). Therefore, the $16 \mathrm{~S}$ gene was not variable enough to evidence any structure in M. amazonicum. This gene is conservative and has a low rate of evolution, which means that it is more precise in discriminating between species than within species. Variation in $16 \mathrm{~S}$ sequences is low or null between sequences from specimens belonging to the same species (see Francisco and Galetti Junior, 2005 for a review). Thus, the homogeneity found in M. amazonicum seems to be related to the conservative nature of this gene.

Previous studies on the systematics of Macrobrachium (Liu et al., 2007; Pileggi and Mantelatto, 2010) have estimated interspecific divergences ranging from 5.5 to $17.5 \%$ for $16 \mathrm{~S}$ and 15.1 to $25.5 \%$ for COI. The intraspecific divergence ranged from 0 to $3.2 \%$ for $16 \mathrm{~S}$ and 0 to $12.6 \%$ for COI. The maximum values $(1.1 \%$ for $16 \mathrm{~S}$ and $3.3 \%$ for $\mathrm{COI}$ ) found in the populations of M. amazonicum fall within the range of intraspecific variation described for the genus. The degree of variation in the COI sequences concords with that found by Peixoto (2002). Consequently, the genetic variability found in our study seems to indicate variation at a population level rather than at a species level.

Our results indicated that because specimens of $M$. amazonicum from Sertãozinho and Miguelópolis (state of São Paulo) share haplotypes and morphological patterns (FGV, LGP, FLM, unpublished results) with coastal populations from northern and northeastern Brazil, they probably originated from these regions and were introduced into São Paulo as part of the process of transplanting the fish P. squamosissimus from reservoirs in northeastern Brazil (see Introduction for details).

Considering that specimens from Avaré share haplotypes and morphological traits (FGV, LGP, FLM, unpublished data) with inland populations from the state of Mato Grosso do Sul in the Paraguay HR, they were probably accidentally introduced into São Paulo or dispersed naturally upstream (Magalhães et al., 2005).

In the 1940s, the National Department of AntiDrought Construction (Departamento Nacional de Obras Contra as Secas - DNOCS) introduced M. amazonicum from the Amazon basin into several reservoirs of northeastern Brazil, as a forage species for carnivorous fishes (Coelho, 1963; Pinto, 1977; Bragagnoli and Grotta, 1995; Paiva and Campos, 1995 apud Da Silva et al., 2004). Specimens from Aquiraz in the state of Ceará may have been introduced for the same reason from natural coastal populations in the state of Pará in northern Brazil, as was revealed by the network haplotypes and morphological revision (FGV, LGP, FLM, unpublished data).

All the inferences concerning the possible origin of the populations from the state of São Paulo and northeastern Brazil were based on the presumptive natural distribution of $M$. amazonicum suggested by Magalhães et al. (2005). However, this presumptive distribution may not be complete, because of a possible lack of records of M. amazonicum (under-sampling) in other regions of the country, as well as in other parts of its range in the Americas.

Haplotype networks and AMOVA evidenced genetic structure between populations of $M$. amazonicum in the same three groups that were revealed by the parsimony and distance analyses. Apparently, the degree of genetic variability found among populations 


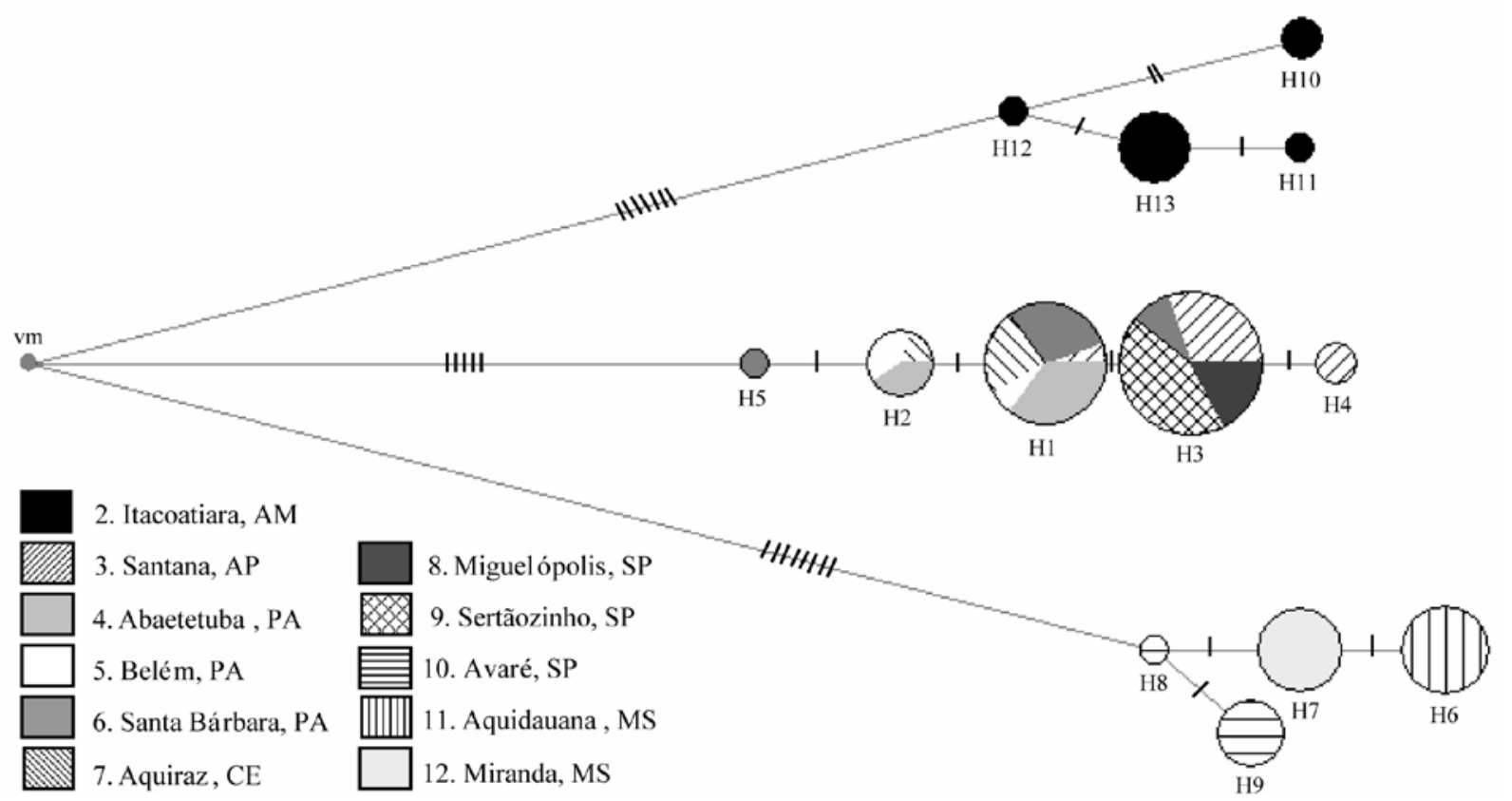

Fig. 6. Haplotype network based on Median-Joining analysis indicating the distribution of each haplotype (H) found in Macrobrachium amazonicum. The haplotype identification is below each circle. Circle size for each haplotype is proportional to the overall frequency in our sample. Each small trace represents a mutational step. vm: median vector. The numbers before the sample site name in the legend boxes correspond to the ones used in Fig. 1. Brazilian states: AM: Amazonas; AP: Amapá; CE: Ceará; MS: Mato Grosso do Sul; PA: Pará; SP: São Paulo. Groups: I - inland population from Amazonian Hydrographic Region (HR); II - inland populations from Paraná/ Paraguay HR; III - coastal populations from northern and north-eastern Brazil.

reflects their geographical distance and habitat fragmentation. The absence of a shared haplotype between groups supports this inference. The geographical isolation and the lack of gene flow (lack of migration and dispersal) between groups are also corroborated by the low levels of genetic variation found within the populations and among the populations within groups. The loss of genetic variability in other populations of freshwater crustaceans is mostly a result of high levels of inbreeding (García-Dávila, 2002; Carini and Hughes, 2004).

Movements of freshwater species are strictly limited by the physical nature and arrangement of the river system. Species with apparently good dispersal abilities frequently show unexpectedly high levels of population subdivision (Carini and Hughes, 2004 for review). Populations of $M$. amazonicum were divided into three groups, which correspond to geographically different environments: inland areas in the Amazonian HR, inland areas in the Paraná/Paraguay HR, and coastal areas in northern and northeastern Brazil. Dry land areas may form an insuperable barrier preventing dispersal and connectivity among aquatic populations, which can cause isolation and genetic divergence in freshwater populations inhabiting separate drainage basins (Carini and Hughes, 2004).

Genetic diversity can enhance adaptation to a particular environment and also expand colonization and distributional boundaries, enabling a species to survive in a wide variety of conditions (Carvalho, 1993). As a result, high levels of genetic variability between populations of the same species may be related to its ecological versatility (Walker, 1992; Leuzzi et al., 2004). This seems to be the case for M. amazonicum, whose populations can be found in habitats with a wide range of salinities (see introduction for references), demonstrating its capability of colonizing different habitats (Odinetz-Collart, 1991a,b). In conclusion, all the arguments presented here lead us to conjecture that variations in the M. amazonicum life-cycle phenotypes, including differences in reproductive strategies, egg size, osmoregulatory and survival capability, adult size, and larval and adult morphology (see Introduction for references), are related to its 
great ecological plasticity developed in response to different environmental conditions (near or far from the sea).

Assessments of intraspecific genetic diversity and population genetic structure provide information of biological and evolutionary interest, and are essential to the success of studies on conservation and maintenance of biological diversity (McMillen-Jackson and Bert, 2004). Macrobrachium amazonicum is heavily exploited by Brazilian artisanal fisheries, particularly in northern Brazil (Odinetz-Collart and Moreira, 1993; Maciel and Valenti, 2009), and is a notable and promising species in freshwater prawn aquaculture in Brazil (Moraes-Riodades and Valenti, 2001, 2004). In this context, we strongly recommend that each group of the M. amazonicum populations should be considered as a distinct genetic stock in any conservation strategy and should be separately managed in order to guarantee the sustainability and maintenance of the genetic resources of the species in Brazil. Furthermore, the existence of genetic structure among M. amazonicum populations should be taken into consideration during the selection of matrices for aquaculture purposes, in order to improve knowledge of the levels of genetic variability among populations.

In conclusion, specimens of M. amazonicum from Brazil showed significant intraspecific variability, in addition to other kinds of variability previously reported (see Introduction for references). Populations were structured in three distinct groups: specimens from inland areas in the Amazonian HR, inland areas in the Paraná/Paraguay HR, and coastal areas in northern and northeastern Brazil. This structure probably results from geographical isolation between them, precluding dispersal and connectivity. If this isolation continues, M. amazonicum may possibly begin a speciation process within its extensive geographical distribution.

Some inferences for M. amazonicum populations can be extracted, but are limited by the nature of our analysis, which was based on two molecular markers (16S and COI mtDNA). At this time, in combination with morphological data (FGV, LGP, FLM, unpublished data), the sequences obtained here can be used as nametags for population identification, and the DNA barcodes are useful to identify the origin of specimens used in different freshwater prawn cultures or of introduced populations of unknown origin. However, we continue efforts to confirm and refine these results, especially in terms of new genes (mitochondrial and nuclear) and more variable molecular mark- ers (microsatellites). We also continue to add coverage at the population level, particularly to elucidate the reasons for the wide distribution of this species in the Americas.

\section{Acknowledgements}

This study formed part of the master's thesis of FGV, and was supported by a fellowship from the Conselho Nacional de Desenvolvimento Científico e Tecnológico (CNPq 134460/073). Additional support for this project was provided by the Fundação de Amparo à Pesquisa do Estado de São Paulo (FAPESP - 02/08178-9), CNPq (Research Grant 471794/2006-6 and 473050/2007-2), and CAPES/DAAD (315/09) to FLM. LGP was supported by Doctoral and Post-Doctoral fellowships from FAPESP (05/50651-1) and CAPES (02630/09-5), respectively. We are deeply grateful to many colleagues and friends (Álvaro Costa, Andrea Bialetzki, Célia Sampaio, Célio Magalhães, Cristiana Maciel, Christoph Schubart, David Véliz, Emerson Mossolin, Fernando D'Incao, Georgina Buckup, Gustavo Hattori, Hertz dos Santos, Liliam Hayd, Luis Pardo, Marcos Tavares, Maura Manfrin, Maria H. Goldman, Rogério Costa, Rogério Faleiros, Rossineide Rocha, Sérgio Rocha, and Wagner Valenti) for help in collecting, making available some essential fresh specimens, and lending materials from collections, and for critical discussion during the preparation of this manuscript. Special thanks are due to all members of the LBSC for all their help during this study, and to anonymous reviewers for their suggestions and contributions toward the improvement of this paper. The support and assistance of the Postgraduate Program in Comparative Biology of FFCLRP/USP are gratefully acknowledged. Dr. Janet Reid (JWR Associates, USA) revised the English text.

\section{References}

Alekhnovich AV, Kulesh VF. 2001. Variation in the parameters of the life cycle in prawns of the genus Macrobrachium Bate (Crustacea, Palaemonidae). Russian Journal of Ecology 32: 454-459.

Amorim DS. 2002. Fundamentos de Sistemática Filogenética. Ribeirão Preto: Holos.

Anger K, Hayd L, Knott J, Nettelmann U. 2009. Patterns of larval growth and chemical composition in the Amazon river prawn, Macrobrachium amazonicum. Aquaculture 287: 341-348.

Augusto AS, Greene LJ, Laure H, McNamara JC. 2007. The ontogeny of isosmotic intracellular regulation in the diadromous, freshwater palaemonid shrimps, Macrobrachium amazonicum and M. olfersi (Crustacea, Decapoda). Journal of Crustacean Biology 27: 626-634.

Baker N, De Bruyn M, Mather PB. 2008. Patterns of molecular diversity in wild stocks of the redclaw crayfish (Cherax quadricarinatus) from northern Australia and Papua New Guinea: impacts of Plio-Pleistocene landscape evolution. Freshwater Biology 53: 1592-1605. 
Bandelt HJ, Forster P, Röhl A. 1999. Median-joining networks for inferring intraspecific phylogenies. Molecular Biology and Evolution 16: 37-48.

Barreto AV, Soares CMA. 1982. Produção de pós-larvas de Macrobrachium amazonicum sob condições de laboratório. Revista Brasileira de Zoologia 11: 51-53.

Bate S. 1868. On a new genus with four new species of freswater shrimps. Proceedings of the Zoological Society of London: 363-368.

Bialetzki A, Nakatani K, Baumgartner G, Bond-Buckup G. 1997. Occurrence of Macrobrachium amazonicum (Heller) (Decapoda, Palaemonidae) in Leopoldo`s Inlet (Ressaco do Leopoldo), upper Paraná River, Porto Rico, Paraná, Brazil. Revista Brasileira de Zoologia 14: 379-390.

Bragagnoli G, Grotta M. 1995. Reprodução do camarão de água doce M. amazonicum (HELLER, 1862) nos açudes públicos do nordeste brasileiro. Revista Nordestina de Biologia 10: 141-154.

Brasil, 2003. Conselho Nacional de Recursos Hídricos (CNRH). Resolução $\mathrm{n}^{\circ} 32$, de 15 de outubro de 2003. Divisão Hidrográfica Nacional.

Bueno SLS, Rodrigues AS. 1995. Abbreviated larval development of the freshwater prawn, Macrobrachium iheringi (Ortmann, 1897) (Decapoda, Palaemonidae), reared in the laboratory. Crustaceana 68: 665-686.

Carini G, Hughes JM. 2004. Population structure of Macrobrachium australiense (Decapoda: Palaemonidae) in Western Queensland, Australia: the role of contemporary and historical processes. Heredity 93: 350-363.

Carvalho GR. 1993. Evolutionary aspects of fish distribution: Genetic variability and adaptation. Journal of Fish Biology 43: 53-73.

Clement M, Posada D, Crandall KA. 2000. TCS: a computer program to estimate gene genealogies. Molecular Ecology 9: $1657-1660$.

Coelho PA. 1963. Observações preliminares sobre a biologia e a pesca dos camarões do gênero Macrobrachium Bate, 1868 (Decapoda, Palaemonidae) no Estado de Pernambuco, Brasil. Trabalhos do Instituto Oceanográfico da Universidade Federal Rural de Pernambuco 3: 75-81.

Da Silva RR, Sampaio CMS, Santos JA. 2004. Fecundity and fertility of Macrobrachium amazonicum (Crustacea, Palaemonidae). Brazilian Journal of Biology 64: 489-500.

Excoffier L, Smouse PE, Quattro JM. 1992. Analysis of molecular variance inferred from metric distances among DNA haplotypes: application to human mitochondrial DNA restriction data. Genetics 131: 479-491.

Excoffier L, Laval G, Schneider S. 2005. Arlequin (version 3.0): an integrated software package for population genetics data analysis. Evolutionary Bioinformatics Online 1: 47-50.

Felsenstein J. 1985. Confidence limits on phylogenies: an approach using the bootstrap. Evolution 39: 783-791.

Francisco AK, Galetti Junior PM. 2005. Genetic distance between broodstocks of the marine shrimp Litopenaeus vannamei (Decapoda, Penaeidae) by mtDNA analyses. Genetics and Molecular Biology 28: 258-261.

Gamba AL. 1984. Different egg-associated and larval development characteristics of Macrobrachium jelskii and Macrobrachium amazonicum (Arthropoda: Crustacea) in a Venezuelan continental lagoon. International Journal of Invertebrate Reproduction and Development 7: 135-142.
Gamba AL. 1997. Biología reproductiva de Macrobrachium jelskii (Miers, 1877) y Macrobrachium amazonicum (Heller, 1862) en Venezuela (Crustacea, Decapoda, Palaemonidae). Acta Cientifica Venezolana 48: 19-26.

García-Dávila CR. 2002. Estudos morfométricos e moleculares comparativos das populações de Palaemonetes carteri (Gordon, 1935) e Palaemonetes ivonicus Holthuis, 1950 (Decapoda: Palaemonidae) na Amazônia. Doctorate Thesis, Universidade do Amazonas e Instituto Nacional de Pesquisas da Amazônia, Brazil.

Gomes-Corrêa MM. 1977. Palemonídeos do Brasil (CrustaceaDecapoda-Natantia). MSc Thesis, Universidade Federal do Rio de Janeiro, Brazil.

Hall TA. 1999. BioEdit: a user-friendly biological sequence alignment editor and analysis program for Windows 95/98/ NT. Nucleic Acids Symposium Series 41: 95-98.

Hasegawa M, Kishino K, Yano T. 1985. Dating the human-ape splitting by a molecular clock of mitochondrial DNA. Journal of Molecular Evolution 22: 160-174.

Hayd LAR, Nakagaki JM. 2002. Os camarões de água doce (Palaemonidae) e a coleta de iscas no Rio Miranda, Pantanal de Miranda. Revista Pantaneira 4: 37-50.

Heckel J. 1840 Johann Natterer's neue Flußfische Brasiliens. Abt. 1. Die Labridontidae. Annalen des Naturhistorischen Museums in Wien 2: 327-470.

Heller C. 1862. Beiträge zur näheren Kentniss der Macrouren. Sitzungsberichte der Akademie der Wissenschaften in Wien 45: 389-425.

Holthuis LB. 1952. A general revision of the Palaemonidae (Crustacea, Decapoda, Natantia) of the Americas. II. The Subfamily Palaemonidae. Occasional Papers of the Allan Hancock Foundation 12: 1-396.

Leuzzi MSP, Almeida FS, Orsi ML, Sodré LMK. 2004. Analysis by RAPD of the genetic structure of Astyanax altiparanae (Pisces, Characiformes) in reservoirs on the Paranapanema River, Brazil. Genetics and Molecular Biology 27: 355-362.

Liu MY, Cai YX, Tzeng CS. 2007. Molecular systematics of the freshwater prawn genus Macrobrachium Bate, 1868 (Crustacea: Decapoda: Palaemonidae) inferred from mtDNA sequences, with emphasis on East Asian species. Zoological Studies 46: 272-289.

Lobão VL, Rojas NET, Valenti WC. 1986. Fecundidade e fertilidade de Macrobrachium amazonicum (Heller, 1862) (Crustacea, Decapoda) em laboratório. Boletim do Instituto de Pesca 13: 15-20.

Maciel CR, Valenti WC. 2009. Biology, Fisheries, and Aquaculture of the Amazon River Prawn Macrobrachium amazonicum: A Review. Nauplius 17: 61-79.

Magalhães C. 1985. Desenvolvimento larval obtido em laboratório de palemonídeos da região Amazônica. I. Macrobrachium amazonicum (Heller, 1862) (Crustacea, Decapoda). Amazoniana 9: 247-274.

Magalhães C. 2000. Diversity and abundance of decapod crustaceans in the Rio Negro Basin, Pantanal, Mato Grosso do Sul, Brazil. Pp. 56-62 in: Willink P, Chernoff B, Alonso LE, Montambault J, Lourival R, eds, A Biological Assessment of the Aquatic Ecosystems of the Pantanal, Mato Grosso do Sul, Brazil. Washington DC: Conservation International.

Magalhães C, Walker I. 1988. Larval development and ecological distribution of central Amazonian palaemonid shrimps (Decapoda, Caridea). Crustaceana 55: 279-292. 
Magalhães C, Bueno SLS, Bond-Buckup G, Valenti WC, Silva HLM, Kiyohara F, Mossolin EC, Rocha SS. 2005. Exotic species of freshwater decapod crustaceans in the state of São Paulo, Brazil: records and possible causes of their introduction. Biodiversity and Conservation 14: 1929-1945.

Mantelatto FL, Robles R, Felder DL. 2007. Molecular phylogeny and taxonomic approach of the crab genus Portunus (Crustacea, Portunidae) from Western Atlantic. Zoological Journal of the Linnean Society 150: 211-220.

Mantelatto FL, Robles R, Schubart CD, Felder DL. 2009a. Molecular phylogeny of the genus Cronius Stimpson, 1860, with reassignment of $C$. tumidulus and several American species of Portunus to the genus Achelous De Haan, 1833 (Brachyura: Portunidae). Pp. 567-579 in: Martin JW, Crandall KA, Felder DL, eds, Crustacean Issues: Decapod Crustacean Phylogenetics. Boca Raton: Taylor and Francis/CRC Press.

Mantelatto FL, Pardo LM, Pileggi LG, Felder DL. 2009b. Taxonomic re-examination of the hermit crab species Pagurus forceps and Pagurus comptus (Decapoda: Paguridae) by molecular analysis. Zootaxa 2133: 20-32.

McMillen-Jackson AL, Bert TM. 2004. Genetic diversity in the mtDNA control region and population structure in the pink shrimp Farfantepenaeus duorarum. Journal of Crustacean Biology 24: 101-109.

Melo GAS. 2003. Famílias Atyidae, Palaemonidae e Sergestidae. Pp. 289-415 in: Melo GAS, ed., Manual de Identificação dos Crustacea Decapoda de Água Doce do Brasil. São Paulo: Loyola.

Miers EJ. 1877. On a collection of Crustacea Decapoda and Isopoda, chiefly from South America, with descriptions of new genera and species. Proceedings of the Zoological Society of London: 635-679.

Mishler BD, Theriot EC. 2000. The Phylogenetic Species Concept (sensu Mishler and Theriot): Monophyly, Apomorphy, and Phylogenetic Species Concepts. Pp. 44-54 in: Wheeler QD, Meier R, eds, Species Concepts and Phylogenetic Theory: A Debate. New York: Columbia University Press.

Moraes-Riodades PMC, Valenti WC. 2001. Freshwater prawn farming in Brazilian Amazonia shows potential for economic, social development. Global Aquaculture Advocate 4: 73-74.

Moraes-Riodades PMC, Valenti WC. 2004 Morphotypes in male Amazon River Prawns, Macrobrachium amazonicum. Aquaculture 236: 297-307.

Murphy NP, Austin CM. 2005. Phylogenetic relationships of the globally distributed freshwater prawn genus Macrobrachium (Crustacea: Decapoda: Palaemonidae): biogeography, taxonomy and the convergent evolution of abbreviated larval development. Zoologica Scripta 34: 187-197.

Odinetz-Collart O. 1987. La pêche crevettière de Macrobrachium amazonicum (Palaemonidae) dans le Bas Tocantins, après la fermature du barrage de Tucurui (Brésil). Revue d'Hydrobiologie Tropicale 20: 131-144.

Odinetz-Collart O. 1991a. Stratégie de reproduction de Macrobrachium amazonicum en Amazonie Centrale (Decapoda, Caridea, Palaemonidae). Crustaceana 61: 253-270.

Odinetz-Collart O. 1991b. Tucurui dam and the populations of the prawn Macrobrachium amazonicum in the Lower Tocantins (Pa-Brazil): a four year study. Archiv für Hydrobiologie 122: 213-227.
Odinetz-Collart O, Magalhães C. 1994. Ecological constraints and life history strategies of palaemonid prawns in Amazonia. Verhandlungen der Internationalen Vereinigung für Theoretische und Angewandte Limnologie 25: 2460-2467.

Odinetz-Collart O, Moreira LC. 1993. Potencial pesqueiro de Macrobrachium amazonicum na Amazônia Central (Ilha do Careiro): variação da abundância e do comprimento. Amazoniana 12: 399-413.

Odinetz-Collart O, Rabelo H. 1996. Variation in egg size of the fresh-water prawn Macrobrachium amazonicum (Decapoda: Palaemonidae). Journal of Crustacean Biology 16: 684688.

Paiva MP, Campos E. 1995. Fauna do Nordeste do Brasil: Conhecimento Científico e Popular. Fortaleza: Banco do Nordeste do Brasil.

Palumbi SR, Benzie J. 1991. Large mitochondrial DNA differences between morphologically similar Penaeid shrimp. Molecular Marine Biology and Biotechnology 1: 27-34.

Palumbi S, Martin A, Romano S, McMillan WO, Stice L, Grabowski G. 1991. The Simple Fool's guide to PCR. Honolulu: Department of Zoology.

Peixoto SNB. 2002. Caracterização molecular e biologia reprodutiva de Macrobrachium amazonicum (Crustacea, Decapoda, Palaemonidae). MSc Thesis. Universidade Federal do Pará, Brazil.

Pettovello AD. 1996. First Record of Macrobrachium amazonicum (Decapoda, Palaemonidae) in Argentina. Crustaceana 69: 113-114.

Pileggi LG. 2009. Sistemática filogenética dos camarões do gênero Macrobrachium Bate, 1868 do Brasil: análises morfológicas e moleculares. Doctorate Thesis. Universidade de São Paulo, Brazil.

Pileggi LG, Mantelatto FL. 2010. Molecular phylogeny of the freshwater prawn genus Macrobrachium (Decapoda, Palaemonidae), with emphasis on the relationships among selected American species. Invertebrate Systematics 24: 194-208.

Pinto ME. 1977. O camarão canela Macrobrachium amazonicum (Heller) em açudes públicos do nordeste do Brasil, administrados pelo Departamento de Obras Contra as Secas (DNOCS). Bachelor Thesis. Universidade Federal do Ceará, Brazil.

Porto LAC. 1998. Estrutura populacional e biologia reprodutiva de Macrobrachium amazonicum (Heller, 1862) (Crustacea, Decapoda, Palaemonidae), na bacia hidrográfica do rio Meia Ponte, Bela Vista de Goiás, GO, Brasil. MSc Thesis. Universidade de São Paulo, Brazil.

Porto LAC. 2004. Estudos morfológicos em populações do complexo Macrobrachium amazonicum (Heller, 1862) (Crustacea, Decapoda, Palaemonidae) em diferentes bacias hidrográficas brasileiras. Doctorate Thesis. Universidade de São Paulo, Brazil.

Posada D, Buckley T. 2004. Model selection and model averaging in phylogenetics: advantages of Akaike information criterion and Bayesian approaches over likelihood ratio tests. Systematic Biology 53: 793-808.

Posada D, Crandall KA. 1998. MODELTEST: testing the model of DNA substitution. Bionformatics 14: 817-818.

Rozas J, Rozas R. 1999. DnaSP version 3.0: an integrated program for molecular population genetics and molecular evolution analysis. Bioinformatics 15: 174-175. 
Saitou N, Nei M. 1987. The neighbor-joining method: a new method for reconstructing phylogenetic trees. Molecular Biology and Evolution 4: 406-425.

Short JW. 2004. A revision of Australian river prawns, Macrobrachium (Crustacea: Decapoda: Palaemonidae). Hydrobiologia 525: 1-100.

Silva MCN, Frédou L, Rosa Filho J. 2007. Estudo do crescimento do camarão Macrobrachium amazonicum (Heller,1862) da ilha de Combú, Belém, estado do Pará. Amazônia: Ciência e Desenvolvimento 2: 85-104.

Swofford DL. 2003. PAUP. Phylogenetic analysis using parsimony (and other methods). Version 4.0b.10. Sunderland: Sinauer Associates.

Thompson JD, Higging DG, Gibson TJ. 1994. CLUSTALW: Improving the sensitivity of progressive multiple sequence alignment through sequence weighting specific gap penalties and weight matrix choice. Nucleic Acids Research 22: 4673-4680.

Torloni CEC, Santos JJ, Carvalho AAJr, Corrêa ARA. 1993. A pescada do piauí Plagioscion squamosissimus (Heckel, 1840) (Osteichthyes, Perciformes) nos reservatórios da Companhia Energética de São Paulo-CESP. Série Pesquisa e Desenvolvimento (CESP: São Paulo) 84: 1-23.

Valencia DM, Campos MR. 2007. Freshwater prawns of the genus Macrobrachium Bate, 1968 (Crustacea: Decapoda: Palaemonidae) of Colombia. Zootaxa 1456: 1-44.

Varón A, Vinh LS, Bomash I, Wheele WC. 2007. POY 4.0 Beta 2602. American Museum of Natural History. Available at http://research.amnh.org/scicomp/projects/poy.php.
Vega-Pérez LA. 1984. Desenvolvimento larval de Macrobrachium heterochirus (Wiegmann, 1836), Macrobrachium amazonicum (Heller, 1862) e Macrobrachium brasiliense (Heller, 1868) (Crustacea, Decapoda, Palaemonidae), em laboratório. Doctorate Thesis. Universidade de São Paulo, Brazil.

Walker I. 1992. Life history traits of shrimps (Decapoda: Palaemonidae) of Amazonian inland waters and their phylogenetic interpretation. Studies on Neotropical Fauna and Environment 27: 131-143.

Wheeler WC. 1995. Sequence alignment, parameter sensitivity, and the phylogenetic analysis of molecular data. Systematic Biology 44: 321-331.

Wheeler WC. 1996. Optimization alignment: the end of multiple sequence alignment in phylogenetics? Cladistics 12: 1-9.

Wiegmann AF. 1836. Beschreibung einiger neuen Crustaceen des Berliner Museums aus Mexico und Brasilien. Archiv für Naturgeschichte 2: 145-151.

Williamson DI. 1973. Larval development in a marine and a freshwater species of Macrobrachium (Decapoda, Palaemonidae). Crustaceana 23: 282-298.

Received: 1 March 2010

Revised and accepted: 9 September 2010

Published online: 21 February 2011

Editor: R. Vonk 


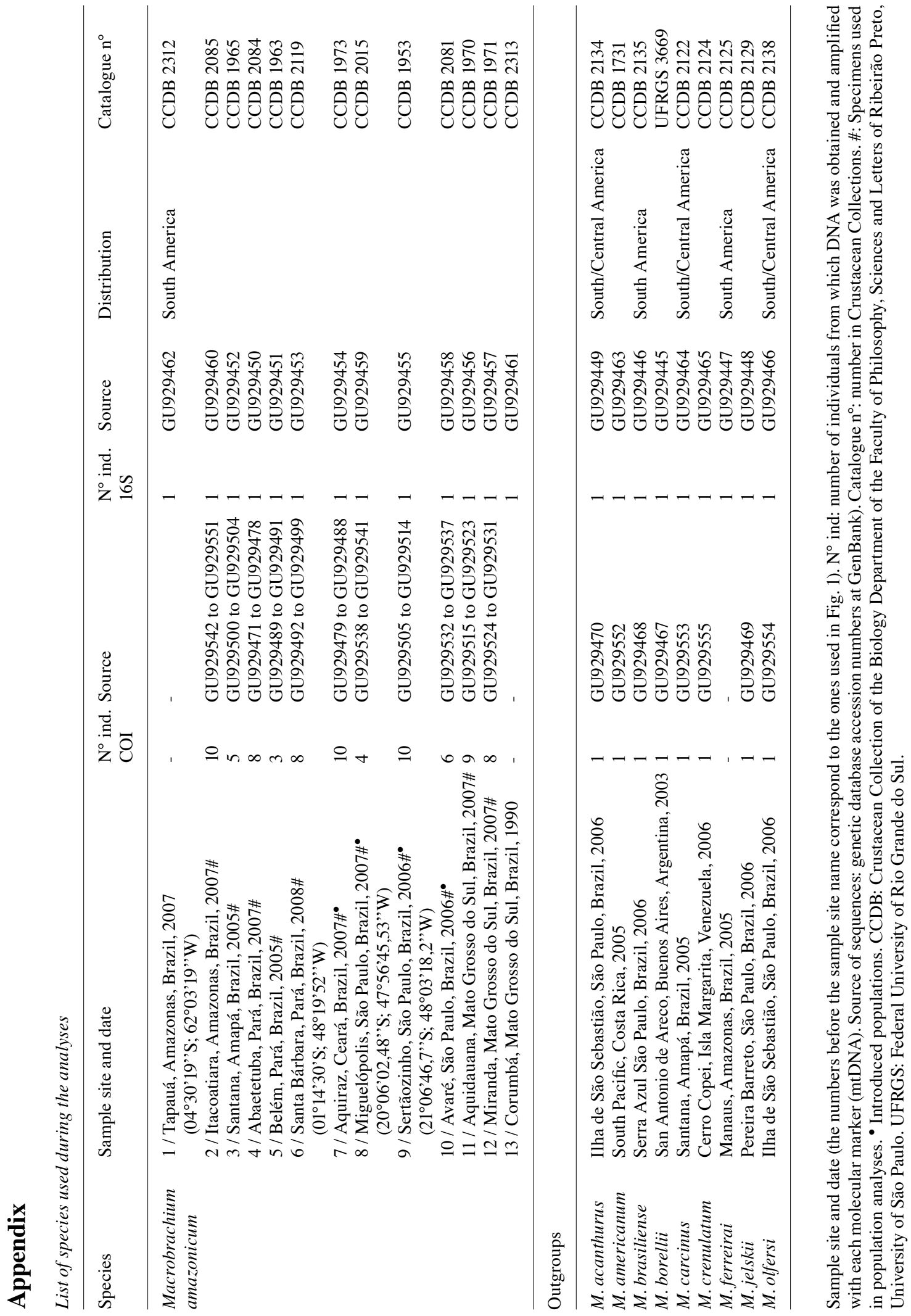


